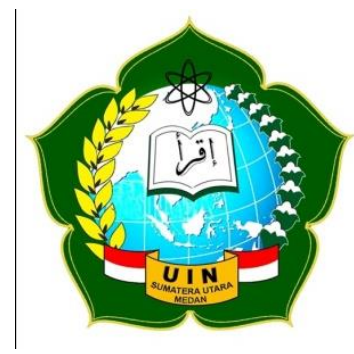

VISION JOURNAL

http://jurnaltarbiyah.uinsu.ac.id/vision

E-ISSN 2745-7982

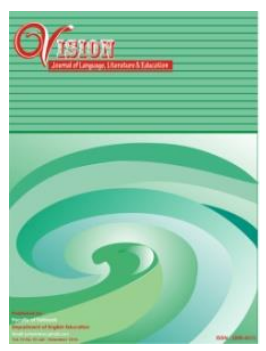

\title{
IMPROVING STUDENTS' WRITING SKILL ON RECOUNT TEXT THROUGH DIARY WRITING
}

\author{
Kaaf Iklilah Siregar
}

Email: kaafiklilahhh@gmail.com

${ }^{1}$ English Education Department, State Islamic University of North Sumatera

\begin{tabular}{|c|c|}
\hline Keywords & Abstract \\
\hline $\begin{array}{l}\text { Keywords: Diary Writing, } \\
\text { Improve, Writing, Writing } \\
\text { Skills, Recount Text }\end{array}$ & $\begin{array}{l}\text { This research was aimed at implementing diary writing as a } \\
\text { medium to improve the writing skills of the eighth grade of } \\
\text { MTs Pondok Pesantren Ulumul Qur'an Medan in the academic } \\
\text { year of } 2020 / 2021 \text {. This research was an action research study. } \\
\text { The participants of this research were } 22 \text { students of grade VIII, } \\
\text { the English teacher, and the collaborator. This research used } \\
\text { two types of data, namely qualitative data and quantitative data. } \\
\text { The qualitative data were obtained through an interview with } \\
\text { the English teacher and the students and observations during } \\
\text { the teaching and learning process. Meanwhile, the quantitative } \\
\text { data were in the form of the results of the students' writing } \\
\text { before the implementation of the actions (pre-test) and after the } \\
\text { implementation of the actions (post-test). The results of the } \\
\text { research showed that there were improvements on the students' } \\
\text { writing skills. The research uses two cycles, each cycle consist } \\
\text { of planning, action, observation, and reflection. The result of } \\
\text { this research shows that there is an improvement of the } \\
\text { students' writing skills in recount text. It can be seen from t-test } \\
\text { calculation in cycle I shows that the score of pre-test } 35.9 \text { and } \\
\text { the score of post-test is } 57.72 \text {. Meanwhile, the cycle II shows } \\
\text { that the score of pre-test is } 57.72 \text { and score of post-test is } 83.86 \text {. } \\
\text { This indicates that by applying of diary writing can improve the } \\
\text { writing skills of the second grade students of MTs Pondok } \\
\text { Pesantren Ulumul Qur'an Medan is accepted. }\end{array}$ \\
\hline
\end{tabular}

Faculty of Tarbiyah and Teacher Training, 1st Floor

Jalan Willem Iskandar Psr V Medan, 20731

Telp. 061- 6622925 - Fax. 061 - 6615685 


\section{INTRODUCTION}

The objective of teaching recount text for students of Junior High School according to curriculum 2013 is the students are expected to be able to produce recount text by using the correct grammar, diction, punctuation, and spelling. The students are also expected to be able to develop and organize ideas so that they can produce a good text. The students could describe the generic structure and the purpose of recount text.

However, the objective above is not achieved yet. That can be proven from the fact that the students still find the difficulties in writing orientation. The students also still make a mistake in arranging the events, as well as re-orientation. The mistakes lead the students in belief that they have ideas but they do not have ability or the skill to express them in a target language.

There are some factors that can cause the students lack in writing recount text, namely internal and external factors. The internal ones are the students' motivation; interest, IQ, and etc. the external ones are material, parents, teaching strategy and others, including media in teaching.

Media in teaching plays an important role to improve students' ability in writing recount text because it is fun and it is not a monotone learning process. By using the media, the teacher not only facilitates the students with information they need, but also can give them some booster for students in understanding the subject. There are many kinds of media that teacher can used; they are picture series, video or movie watching and diary writing.

Diary can improve students' writing skill in recount text because diary as a media to express students ideas in written form. Diary can make students to be more motivated and easier them to express their feeling by writing diary. Students can write about their feeling, experiences, wishes, and freely write their ideas. Diary writing usually done every day which is becomes a habit for students. The frequency of writing something in their daily life will improve students' ability in writing skill. Students will become more fluent in writing something and reduce in making some errors in writing.

Therefore, the researcher wants to conduct a research about "Improving Students' Writing Skill on Recount Text through Diary Writing at Eight Grade of MTs Pondok Pesantren Ulumul Qur'an Medan”. 


\section{LITERATURE REVIEW}

\section{The Writing Skill on Recount Text}

According to Oshima and Ann (2007) writing is defined as some steps of action that involved thinking of ideas, transferring it into some words, and reviewing it until the writing expresses exactly what the writer wants to say to the reader. In this definition, writing as a continuation action involved thinking and transferring ideas into word and sentences, and then reviewing the writing product to make it satisfied to be read and express writes ideas exactly. Furthermore, Meyers (2005) stated that discovering, organizing, putting ideas on paper, reshaping, and revising are a bundle of a writing process. In the theory, writing is defined as a process of doing something dealing with problem and difficulty in discovering interesting ideas, organizing and putting them on paper that is appropriate with the writing project. Then, reshaped and revised the writing product to make it better and understandable by the reader.

Based on those definitions, the researcher concludes that writing skill is an ability to write as natural as possible, write with the accuracy of grammar, coherent and authentic ideas, write with fluent, has clear an specific purpose of writing and using some strategies for dealing with the problems in writing process in order to get the best writing product.

Recount text is one of text types that really common used in writing. Recounting itself is an activity where we are telling people about something that has happened in our lives. It might be about exciting things that happened on our holiday or what we did at the last weekend. Recount text is a text that helps students in developing their experience into writing.

Based on definition above, the researcher concludes that writing skill on recount text is an ability to write with fluency, as natural as possible with the accuracy of grammar, the coherent and authentic ideas, clear purpose of writing and using some strategies for dealing with the problems in writing and retell the past story, experiences or events in past tense or past perfect tense.

\section{The Diary}

Akbar et el on their study entitled 'The Effect of Diary Writing on EFL Students" Writing and Language Abilities' concerned that diary can be defined as daily log activities that record the events that happen during the day. It is updated on daily basis, private and written for the writer only. A diary is usually handwritten that is used to express personal feelings, thoughts, and experiences on daily life, arranged by date, and not for publication to 
read. From the definitions, we can say that diary is like a book that we write with our hands where we share our feelings, thoughts, and experiences on daily basis. Moreover, not many people can read it but the author because it's private and personal.

According to Bolton (2001), diary contains stories of happenings, hopes, and fears about what might happen, memories, thoughts, ideas, and all the writer's feelings and it is one of the oldest forms of literature in the west. From this definition, we got the point that the writer can write all their feelings about their future and past stories or hopes in diary. It is suitable to be used in writing activity to develop students' ideas in writing process. Further, Fitzpatrick (2005) stated diary is a personal record of a writer's experience and it is usually private. By writing a diary, the students can explore and develop their ideas from real life experience, means they are trained to be a sensitive writer who can get the inspiration in writing whatever happened in their daily life. It helps students to solve their problems in getting and developing ideas in writing.

In the teaching and learning activities, using writing diary technique in teaching recount text put in the modeling of the stage step. Teacher gives a model of diary writing and then explains it. For the task, the teacher asks students to write their past experiences in the diary. Students should practice about how to write a proper English text starting from their daily life because what they write is actually an example of recount text.

From the statement above, based on explanation of writing and diary, researcher can be concluded that writing diary is joyful activity for the students in writing their idea and digging their idea freely. In writing diary, someone can share what they have in mind after they Show or felt something. Writing diary is on of media in teaching recount text. Hopefully it would make students excited in the teaching learning process.

\section{METHOD}

According to Arikunto (2012), classroom action research (CAR) is one of the inquiry research types that has reflective, participative, and collaborative characteristic which have the goal to increase the system, method, process, competence and situation of learning process in the classroom. It is one way to repair and improved educational services that organized in improving the quality of the overall school program. CAR is expected to be able repair and improve the quality of teaching and learning in the classroom. 
Based on that, this research will use qualitative method and quantitative method. Qualitative method is descriptive data research from individual attitudes and behaviors which can be observed during the learning process in the classroom. It means this kind of this research involves the researchers in the calculations, numbers, and quantity.

In CAR, the researcher will collect the data by conducting several cycles. Each cycle contains four steps, they are: planning, action, observation, and reflection.

\section{Planning}

Planning is a preparation before doing an action research; it is the beginning of research process to conduct treatments or after making sure about the problem of the research. Researcher prepares some materials that will use in the whole learning process in the classroom, such as lesson plan based on the teaching material, prepare the materials that needed in the learning process, and prepare the test for observation and interview.

\section{Action}

This section discusses about the activities that will be taken by the researcher based on the planning. Researcher tries to test how much students' abilities to understand in writing recount text, give students explanation in learning process, give students assignments to write a diary in individual, evaluate written mistake from their work and make summarize about materials.

\section{Observation}

A researcher has to observe all events or activities during the research in this step. Researcher observes the situation in class during lesson, observers of students' attitude when give lesson explanation, students doing task or quiz, and students' difficulties in learning process.

\section{Reflection}

Reflecting is the examining effort on the success or failure in reaching the temporary purposes in the classroom in meaning to determine the alternative steps that are probably made to the final goals of the research. 


\section{FINDING AND DISCUSSION}

The researcher gave a pre-test to the students before the cycle I was conducted. Before the researcher conducted this study, the researcher gave a writing test and interview to the students. The used of writing test is to know the students' writing skill on recount text. The result of pre-test who passed the Kriteria Ketuntasan Minimal (KKM) was 0 students. While there were 22 students or all students who did not passed the KKM. On the other word, the percentage of students who success on the pre-test was $0 \%$ and who was unsuccessful on the pre-test was $100 \%$.

The number of students who took the test was 22 students. After the test conducted, it was found that all of the students could not passed the minimum score 75 . The total of the students' score from the pre-test was 790. So, the mean score was 35,9.

Based on the result above, it can be seen that the students' writing skill on recount text was still low. It can be seen from the mean score was 35,9. The percentage of the students who passed the test was $0 \%$. There were 22 students who did not passed the standard minimum criteria on English lesson.

The quantitative data above was supported by the qualitative data which obtained from the interview result from the English teacher. The result of interview from the teacher found that the students felt bored, not interested and despaired when the teacher taught English subject. The students were still afraid of making mistakes when they write because they were lack of vocabulary and lack of ideas to write. This result is strengthened by the interview result with teacher:

Students do not have interested in English subject especially in writing. They felt bored and not paying attention when the teacher taught English subject. Students were confused and difficult when they write English because they were lack of vocabulary and lack of ideas to write. Some of them even cannot write basic writing properly because English subject is still strange to them.

\section{Cycle I}

From the result of the interview above, it can be conclude that the students' writing skill on recount text was still low. The students got some problems in writing. Therefore, the researcher continued the preliminary data to the first cycle. 


\section{1) Planning}

Before conducting the research, the writer prepared the research instruments, they were: a) Lesson plan: it was used as guidance and controlling the learning process. b) Material: the content of material was recount text was taken from several sources. The researcher formed the material into a power point. c) Teaching aid: the researcher used a diary writing as the major technique in the application of the teaching of the recount text. The students make their own story telling into diary writing. d) Test: it conducted both pre-test and post-test was a test given to the students before the researcher conveyed the material using teaching technique, while post-test was a test given to the students after the researcher conducted the device.

\section{2) Action}

Implementation of the learning process in cycle I was done four meetings started from Saturday, November $28^{\text {th }} 2020$ to Saturday, December $26^{\text {th }} 2020$. This cycle include pre-test, learning application and post-test. The researcher and collaborator entered the English class. The class was started by praying together and introduced the researcher to the students. Then, the researcher informed the students about activities to be implemented.

The first stage of the action of cycle I is pre-test. Pre-test given by the researcher was done on Saturday, November $28^{\text {th }} 2020$. Researcher shared the worksheet to the students. She also went around the class to check the students' work and to help students' difficulties. Most of them have difficulties in understanding the vocabularies. After the time for the test finished the researcher collected the students' work.

The second stage of the implementation of cycle I is learning activity. The activity continued with implementation of the learning was done on Saturday, December $5^{\text {th }} 2020$. In this meeting the researcher explained about the material of recount text as material enrichment and understanding to students. When the researcher explained it, the students listened and paid attention to her. The researcher explained in detail about the materials of recount text. The researcher explained the material of recount text ranging from meaning of the recount text, the purpose of the recount text, generic structures of the recount text, characteristics of the recount text and the example of the recount text, according with lesson plan that had created.

After conducted a detailed explanation, the researcher gave the chance for students to ask questions according with the level of understanding of each students. Then the researcher explained to the students so that the students can understand the materials of recount text more deeply. The next step is to test the understanding of the students about recount text. 
Researcher tested the students' understanding by asked them to analyzing a recount text and gave the questions to the students. When the students' quite understand, the researcher gave a quiz for students to test the deeper understanding in 30 minutes then collected to the researcher.

The last step in the application of learning activities was giving homework to students. This is a staple of diary writing technique application intended and would like to be applied by the researcher. At this stage, students were asked to write a diary activity which had the concept of storytelling that was written in a diary, which was given a time marker in detail as free themes that wanted to be told of an event, the date and place. By conducting this technique was expected that students can be lightly and happily in conducting their homework with no load. This is because; basically everyone likes to share the experience that they experienced. This technique adapted on a daily activity that many people did when they are happy updated their status in social media, like facebook and twitter.

The last stage of the overall activities in the application of learning activity in cycle I was the post-test. Post-test was done on Saturday, December $26^{\text {th }} 2020$. The teacher distributes worksheets to students. The researcher gave the duration time in 40 minutes in afternoon class as usual as school agenda. The worksheets created with degree of level similar to the pre-test questions before but with different questions. This was done aim to measure the outcomes of learning activities that conducted in the core activities of the learning activities that have prepared previously by the teacher through the lesson plan. This post-test would provide results of a study that had done by students whether the results of this study had been successful and improve the results of the pre-test before.

\section{3) Observation}

The observation was proposed to find out the information about activities teaching and learning process. The observation included the attitude of the students, behavior and it was also seen that the students participate in teaching and learning process. Thus, the result of observation was collected as the data.

The result of the post test cycle I, it was showed the total score of the students' was 1270 and there were 22 students' who took the test. So, the mean that the researcher got was 57.72. The percentage of the students' score in post test cycle I was 6 students passed the score 75 or up 75 was $27.27 \%$. 
The quantitative data were strengthened by qualitative data which of obtained from interview and observation sheet. The observation sheet was done to observe how students' attitude and problem in teaching and learning process. The students were enjoyable and enthusiastic about the topic and they were able to write a diary, and the students can develop their idea because can discuss the meaning with their friend. The result of the teacher's and students' interview can be seen from the interview of English teacher about the students' writing skill in recount text, as follows: Menurut saya, saya rasa ini adalah satu langkah yang bagus yang bisa saya terapkan kepada mereka, selain media diary dapat sangat mudah, dengan menulis dary tiap hari akan meningkatkan kemmpuan menulis siswa. It was strengthened by the result of students' interview as follows: "Awalnya membingungkan miss, ternyata semakin lama menulis maka jadi terbiasa dan saya jadi lebih muah mengingat kosa kata baru dalam bahasa Inggris.

During this activity, researcher and her collaborator were observing all the activities happened during the learning process. They also observed and monitored all the students' attitude, response and attention to the learning activity. But the result of this learning needs improvement. There were some students showed that they had difficulties in writing recount text. Most of them were lack of vocabularies. Other weaknesses were on the grammar and structure. Nevertheless, there were some other students had a good skill in writing but still need guidance to improve.

4) Reflection

Based on the result of the data and observation on the first cycle of learning process, it was obtained the reflection as follows:

a) There are students who should require more intensive guidance are Baginda Paripunan Siregar, Ahmad Al Muqaffi, Muhammad Fadhil Amru, Muhammad Tajir Al Anshori, Parhan Kholis Siregar, Syakir Abdul Matin and few students. They have difficulty in some writing skills and less in mastering the vocabulary from the other students. This condition is normal but the teacher have mission to improve the students' capability and mastering the vocabulary by giving motivation and support.

b) The use of diary writing hopefully can help student to comprehend recount text. This is because basically everyone likes to share the experience that they experienced. 
This technique adapted on a daily activity that many people did when they are happy updated their status in social media, like facebook and twitter.

c) In the next cycle researcher still used the same device so the students will understand more about recount text with the learning activity. Therefore, the result of the next cycle will improve as expected.

From the students' score and the students' response above, the students' writing skill in post test cycle I was still low. Because the students' writing skill on recount text in post test I was categorized not success. The researcher decided to continue in cycle II in hoping the best one.

\section{Cycle II}

Learning process in cycle II was a revision from the result of previous cycle. It was same with cycle I that consisted of planning, implementation of the action, observation and reflection.

1) Planning

Before conducting the research, the writer prepared the research instruments, they were: a) Lesson plan: it was used as guidance and controlling the learning process. This lesson plan revised the learning process in cycle I. b) Material: the content of this lesson plan was a new material which explained about diary text was taken from several sources. The material formed into a power point. c) Teaching aid: the researcher used a diary writing as the major technique in the implementation of the learning of the recount text. It used as teaching aid d) Test: post test only.

2) Action

Different with the implementation of the first action in cycle $\mathrm{I}$, in the second implementation in cycle II consist of two stages only.

In this section the researcher still used the same device it was to continue the previous teaching learning process. Different from the cycle I the researcher did not give students pretest as before to conveying the material. The researcher had opinion that on pre-test was enough to representing the comparison value.

The first stage of the implementation of cycle II is learning activity. The activity continued with implementation of the learning was done on Saturday, January $9^{\text {th }} 2021$. In this meeting the researcher continued with new material about the material of diary text as 
enrichment and understanding to students. When the researcher explained it, the students listened and paid attention to him. The researcher explained in detail about the materials of diary writing. The researcher explained the material of diary writing ranging from meaning of the diary text, the benefits of the diary text, the steps of the diary text, the example of the diary text and the difference between diary text and recount text, based the lesson plan that had created.

After conducting a detailed explanation, the researcher gave the chance for students to ask questions according with the level of understanding of each students. Then the researcher explained to the students so that the students can understand the materials of diary text and how to write it more deeply. For the next step, to test the comprehension of the students about diary text, researcher tested the students' comprehension by asked them to analyzing a diary text and gave the questions to the students. After quite understand, then the researcher gave a quiz for students to test the deeper comprehension in 30 minutes then collected to the researcher.

The last step in the application of learning activities was gave homework to students. This is the main of diary writing technique implementation intended and would like to be applied by the researcher. At this stage, same with the previous activity students were asked to write a diary activity which had the concept of storytelling that was written in a diary, which was given a time marker in detail as free themes that wanted to be told of an event, the date and place. By conducting this technique was expected that students can be lightly and happily in conducting their homework with no load. This is because basically everyone likes to share the experience that they experienced. This technique adapted on a daily activity that many people did when they are happy updated their status in social media, like facebook and twitter.

The last stage of the overall activities in the application of learning activity in cycle II was the post-test. Post-test was done on Saturday, January $16^{\text {th }} 2021$. The researcher distributes worksheets to students. The researcher gave the duration time in 40 minutes in afternoon class as usual as school agenda. The worksheets created with degree of level similar to the pre-test and post-test questions in cycle I but with different questions. This was done aim to measure the outcomes of learning activities that conducted in two learning activities in cycle I and cycle II that have prepared previously by the teacher through the lesson plan. This post-test would provide results of a learning that had done by students. Whether the results of this learning had been successful and improve the results of the pretest and post test before in cycle I. and the results could be seen in the table below. 


\section{3) Observation}

The observation was proposed to find out the information about activities in learning process. In the second cycle, it can be seen that the students' more active in learning process. The students' gave the good response and also well in asking and answering the questions. The researcher used differences style to teach the students, so the students' liked to learn about recount text by diary writing.

Quantitatively, the score of the students' in cycle II, it can be seen that the students who took the test were 22 students. The total score of the students' was 1845 . So, the mean of the students' score was 83.86. The percentage of the students' score of the post test cycle II was 20 students who reached the score up 75 was $90.90 \%$. It can be conclude that post test cycle II was successful.

There were two results in the cycle II that found by the researcher. They were qualitative and quantitative result. From the qualitative result it can be seen that using diary writing in learning process became more interesting and enjoyable, it can make the students to practice more in writing without being forced. From observation sheet, the researcher explained the generic structure and example of recount text; the students could follow the researcher's instruction well. So, the post - test cycle II was categorized successful.

At this stage students seemed increasingly comprehend the recount text and increased in their writing skill of recount text form. The students' activeness improves as well. Students seemed more confident to write a recount text. The pleasures that they have in writing a story, they will be more active in writing what they want to share with others, automatically the students has increased their writing skills.

From the result of this cycle, it shows that there is an improvement compared with the previous cycle. So it means that the students more skilled with the writing. It is also shows that the students made an increase in their writing skills in recount text.

\section{4) Reflection}

After analyzing the result of cycle II, the researcher concluded that diary writing can improve students' writing skilled. In addition students' skills increased and they more active to telling story into writing.

Based on the result of data analysis and observation in cycle II, it is obtained that the use of diary writing is able to stimulate the students' writing skilled. This following table is the score of students' worksheet in cycle II consist of post-test only. 
Based on the explanation above, it can be conclude that the researcher felt the cycle could be stopped. Most of the students' score increase from the cycle I to cycle II. Finally, the researcher get the result of this cycle is suitable with the researcher' target. Based on the comparison of the results above there is an increase percentage who gets approach KKM from $30 \%$ to $90 \%$. It is successful based on the percentage in the cycle I and cycle II. Even though the result did not reached $100 \%$ but the researcher had fulfill the target is $80 \% 20$ students from 22 students. Its mean that diary writing is able to improve students' writing skilled in recount text.

From the result of the data analysis in cycle I and II, the researcher analyzed the students' improvement from each cycle. The improvement as follow:

\section{The Percentage of Students Score up to 75}

\begin{tabular}{|c|c|}
\hline Writing Test & Percentage \\
\hline Pre Test & $0 \%$ \\
\hline Post Test Cycle 1 & $57.72 \%$ \\
\hline Post Test Cycle 2 & $90.90 \%$ \\
\hline
\end{tabular}

The table show that the improvement of the students' writing skilled is improve from the cycle I to cycle II. Based on the procedure, applying the diary writing is succeeding to improve students writing skilled. The table above shows the differences of t-calculation in each cycle.

Beside, the mean of pre-test and post-test in each cycle also increase. It can be seen in table above. The mean of pre-test in cycle I is 35.9 while the post-test is 57.72 . The mean of pre-test and post-test in cycle II is 57.72 and 83.78 .

It is prove that the students' writing skills improved in each cycle. The students finally can do the test. This improvement can influence the students' score. Then, the score of post-test is better than pre-test so it means that the students writing skills are enhance after applied the diary writing.

From the explanation above, it can be stated that the qualitative data result were obtained from interview, observation sheet, and documentation. It was taken that the students' writing skill on recount text was improved in the classroom in every cycle. It was shown that the using of diary could help the students to improve their writing. 
The researcher could be concluded that diary writing can improve the students' writing skill on recount text. It could be showed from the quantitative data which were the students' score in pre test, post test cycle I, and post test cycle II was got higher and successful, it could be seen from the qualitative data, the researcher could controlled the class and students more interested and active in learning English especially in reading recount text.

\section{CONCLUSION}

Based on the result of the data analyzed in this research, it can be concluded that: (a) The implementation of diary writing as technique in the teaching and learning process of writing is believed to be an effective way to improve the students' writing skills. The students got better skills on the purpose of a recount text and the process of how to write a recount text. The students could minimize their writing problems especially in the five aspects of writing, that is the content, the organization, the vocabulary, the language use, and the mechanics aspect in the writing practice. Through the given feedback and regular writing, the students did not make the same mistakes in their future writing so that they could perform better writing from time to time. (b) The students' skills in writing can be improved by diary writing as method in teaching learning process. It can be proven by the score of pre-test and post-test in cycle I. The score of post-test was greater than pre-test.

The cycle II shows that the score of pre-test and score of post-test is improved. It means that there is significant difference in the mean between pre-test and post-test. This indicates that "diary writing" can improve the students 'skills in writing of the eighth grade students' of MTs Pondok Pesantren Ulumul Qur'an Medan in the academic year 2020/2021.

Using diary writing could give an improvement by calculating using t-test calculation. T-test is formula to know the significant differences between pre-test and post-test. From the t-test, it can be seen that there is improvement from the first cycle to the second cycle.

\section{REFERENCE}

Arikunto, Suharsimi, dkk. 2012. Penelitian Tindakan Kelas. Jakarta: Bumi Aksara.

Bolton, G. 2001. Reflective Practice. London: Paul Chapman Publishing Ltd.

Fitzpatrick, M. 2005. Engaging Writing Paragraph and Essay. London: Longman.

Meyers, A. 2005. Gateways to Academic Writing: Effective Sentences, Paraghraps, and Essays. NewYork: Longman. 
Oshima, A. \& Ann, H. 2007. Introduction to Academic Writing. New York: Pearson Longman,.

Taqi, H. A., Akbar, R. S., Al-Nouh, N. A., \& Dashti, A. A. (2015). The effect of diary writing on EFL students' writing and language abilities. British Journal of Education, 3(2), 75 91. 